\title{
Effect of a nutrition education programme on nutritional status of children aged 3 - 5 years in Limpopo Province, South Africa
}

\author{
L F Mushaphi, ${ }^{1} \mathrm{PhD}$; A Dannhauser, ${ }^{2} \mathrm{PhD} ; \mathrm{C}$ M Walsh, ${ }^{2} \mathrm{PhD} ; \mathrm{X}$ G Mbhenyane, ${ }^{3} \mathrm{PhD} ; \mathrm{F}$ C van Rooyen, ${ }^{4} \mathrm{MCom}$ \\ ${ }^{1}$ Department of Nutrition, School of Health Sciences, University of Venda, Thohoyandou, South Africa \\ ${ }^{2}$ Department of Nutrition and Dietetics, School of Allied Health Professions, University of the Free State, Bloemfontein, South Africa \\ ${ }^{3}$ Division of Human Nutrition, Faculty of Medicine and Health Sciences, Stellenbosch University, Cape Town, South Africa \\ ${ }^{4}$ Department of Biostatistics, School of Health Sciences, University of the Free State, Bloemfontein, South Africa
}

Corresponding author: LF Mushaphi (lindelani.mushaphi@univen.ac.zaormushaphil@gmail.com)

\begin{abstract}
Background. Globally, the prevalence of chronic and acute malnutrition and micronutrient deficiency is high in young children, especially in developing countries. Nutrition education is an important intervention to address these challenges.

Objective. To determine the nutritional (anthropometric and micronutrient) status of children aged $3-5$ years at baseline and post intervention.

Methods. A pre-test-post-test control group design was chosen, which included eight villages (four villages in the experimental group (E); four villages in the control group (C)). The Nutrition Education Intervention Programme (NEIP) comprised ten topics emphasising healthy eating, hygiene and sanitation.

Results. At baseline, $15 \%$ (E) - 22.4\% (C) of children were stunted. Very few children were underweight in both groups $(\mathrm{E}=2.5 \%$; $\mathrm{C}=$ $8.2 \%)$ and only $2.5 \%$ of children were wasted in the $\mathrm{E}$ group at baseline. At baseline, about a third of children in both groups ( $\mathrm{E}=38.5 \%$; $\mathrm{C}=30.8 \%)$ had marginal vitamin A status $(100-199.9 \mu \mathrm{g} / \mathrm{L})$, while $<10 \%$ in the $\mathrm{E}$ group $(\mathrm{E}=7.7 \%)$ had vitamin A deficiency $(<100 \mu \mathrm{g} / \mathrm{L})$. According to the categories for indicators of iron status, the number of children who were in the 'adequate' category for serum iron, serum ferritin, serum transferrin and percentage transferrin saturation did not change in both groups at postintervention assessment. In both groups, nutritional status of children (both anthropometric and blood variables) did not change significantly following intervention. Conclusion. The nutrition intervention did not have a significant effect on indicators of nutritional status, possibly owing to its short duration (12 months) and the fact that food supplementation was not included.
\end{abstract}

S Afr J Child Health 2015;9(3)98-102. DOI:10.7196/SAJCH.7958

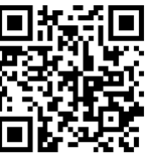

Globally, the prevalence of acute and chronic malnutrition and micronutrient deficiency is high in young children, especially in developing countries, where malnutrition affects one out of every three preschool children. ${ }^{[1]}$ It has been estimated that 178 million children $<5$ years of age suffer from chronic malnutrition..$^{[2]}$ According to the South African (SA) National Health and Nutrition Examination Survey (SANHANES-1), ${ }^{[3]}$ children aged 0 - 3 years have the highest prevalence of stunting (26.9\% for boys and $25.9 \%$ for girls).

Recently, the United Nations Sub-Committee on Nutrition $(\mathrm{UNSCN})^{[4]}$ estimated that 163 million children in developing countries are vitamin A deficient. Furthermore, the Administrative Committee on Coordination/Sub-Committee on Nutrition (ACC/ $\mathrm{SCN})^{[5]}$ has calculated that more than three billion people in developing countries are iron deficient. Almost 50\% of preschool children in developing countries suffer from iron-deficiency anaemia. ${ }^{[6]}$ In sub-Saharan Africa, 36 million preschool children are affected by vitamin A deficiency. ${ }^{[7]}$ Although the extent of clinical vitamin A deficiency in SA is not as severe as it is in some other subSaharan countries, one in three children was identified as marginally vitamin A deficient in the SA Vitamin A Consultative Group $\left(\right.$ SAVACG) ${ }^{[8]}$ study, and more recent data from the SANHANES-1 indicated that $43.6 \%$ of children $<5$ years old in SA have vitamin A deficiency. ${ }^{[3]}$ In the SAVACG ${ }^{[8]}$ study, it was reported that $21 \%$ of preschool children were anaemic, while the SANHANES- ${ }^{[3]}$ found that $15.2 \%$ of young children aged 24 - 35 months and $10.9 \%$ of children aged 36 - 47 months were anaemic.

Micronutrient deficiencies have a significant effect on human welfare and on the economic development of poorer countries. Micronutrient deficiencies can lead to serious health problems, including blindness, mental retardation and reduced resistance to infectious disease, and in some cases death. ${ }^{[9]}$ Micronutrient deficiencies substantially affect the nutritional status, health and development of a significant percentage of the population in many countries, both developed and developing. ${ }^{[9]}$

The high prevalence of micronutrient deficiencies seen in developing countries is mainly due to the immediate inadequate intake of dietary energy and protein, the low content of micronutrients in the diet and poor bioavailability. ${ }^{[10]}$ Poor dietary intake of energy and protein and frequent infections are also associated with poor growth and development in children. ${ }^{[1]}$ Furthermore, poor dietary intake and frequent infections contribute to half of all anaemia observed in children. ${ }^{[11]}$ In SA, the diets given to children in most rural areas lack variety, also contributing to malnutrition. Indigenous foods can play an important role in improving dietary variety of rural populations. Therefore, the indigenous and traditional food systems of poor and rural communities need to be promoted in the search for solutions to the global problems of poverty, hunger and malnutrition. ${ }^{[12]}$

According to Aphane et al. ${ }^{[13]}$ most countries are encouraged to improve the micronutrient status of the population by changing practices at the household level and by protecting the nutritional 
benefits of traditional practices that are eroding because of factors such as urbanisation and modernisation. When income increases, people often reduce breastfeeding, stop gathering wild foods and eat fewer green leafy vegetables owing to ignorance or poor knowledge of nutrition. Nutrition education may play an important role in improving the nutrition knowledge and the way caregivers feed their children, which could contribute to an improvement of the nutritional status of the children.

\section{Methods \\ Study design}

A pre-test-post-test control group design was applied. The data were collected at baseline in both the control (C) and the experimental (E) groups. After the baseline, the $\mathrm{E}$ group received nutrition education, while the $\mathrm{C}$ group did not. The intervention programme was implemented for a period of 12 months, after which anthropometric and micronutrient status were determined again.

\section{Study population}

The study population included caregivers and children aged 3 - 5 years living in Limpopo Province. For the purpose of the study, 'caregiver' refers to the legal guardian of the child or the mother of the child.

\section{Sample size}

Simple random sampling was used to select 8 villages (4 E, 4 C) from Mutale Municipality in Vhembe District, Limpopo, SA. All households with children who met the inclusion criteria and who agreed to participate were included in the study. A total of 129 children aged 3 - 5 years and 125 caregivers were included at baseline. Post intervention, 89 children and 86 caregivers were available to participate. This translates to a $69 \%$ response rate for both children and caregivers. Blood samples were only drawn from the children whose caregivers gave consent, resulting in low numbers.

\section{Data collection}

At baseline, four trained fieldworkers interviewed participating caregivers, using the local language (Tshivenda), on feeding practices and nutrition knowledge. On the same day, the trained fieldworkers also took anthropometric measurements using standard procedures as described by Lee and Nieman. ${ }^{[14]}$ A professional paediatric nurse was responsible for taking blood samples a few days after the interview. The blood samples were used to determine the iron and vitamin A status of the children before and after the intervention.

\section{Nutrition Education Intervention Programme (NEIP)}

The NEIP was based on the SA food-based dietary guidelines $(\mathrm{FBDG})^{[15]}$ and SA paediatric FBDG. ${ }^{[16]}$ Mypyramid for children ${ }^{[17]}$ and dietary guidelines for children ${ }^{[18]}$ were also used. FBDG are practical and simple messages that inform the general public on which foods and eating habits will provide the nutrients they need to promote overall health and prevent chronic diseases. ${ }^{[15]}$ In SA, the FBDG were developed based on affordable, available foods that are widely consumed. ${ }^{[15]}$ In addition, the FBDG were compatible with different cultures and eating patterns of the target population. ${ }^{[15]}$

\section{Implementation of the NEIP}

The NEIP comprised 10 topics, namely: enjoying a variety of foods; guidelines for feeding children 3 years and older; hygiene and sanitation; making starchy foods the basis of most meals; eating plenty of vegetables and fruits every day; eating dry beans, split peas, lentils and soya; recommending that chicken, fish, meat, milk or eggs be eaten daily; using salt sparingly; eating fats sparingly; and using food and drinks containing sugar sparingly and not between meals. These were explained to the E group over a period of 12 months. The E group was visited twice a week during the implementation period.
Duration of each group discussion presentation was 20 - 30 minutes. The size of the groups of caregivers during the nutrition education presentation sessions ranged from 6 to 20. The discussion approach was chosen because it promotes interaction between group members and allows caregivers to participate actively in the programme.

\section{Data analysis}

Data were analysed by the Department of Biostatistics of the University of the Free State (UFS) using Statistical Analysis Software (SAS) version 9.2 (SAS Institute Inc., USA). Continuous data were expressed using median, minimum and maximum values. Categorical data were described using frequencies and percentages, and $95 \%$ confidence intervals (CIs) were used for median and percentage differences to determine the effect of the intervention programme.

\section{Ethical consideration}

Ethical approval was obtained from the Ethics Committee of the Faculty of Health Sciences, UFS (ETOVS No. 24/06). Permission to conduct the study in the villages was obtained from local leaders. Written informed consent was obtained from caregivers.

\section{Results}

\section{Sociodemographic data}

The $\mathrm{E}$ and $\mathrm{C}$ groups were comparable at baseline in terms of sociodemographic data. In both groups, $>60 \%$ of caregivers had secondary education $(\mathrm{E}=64.6 \% ; \mathrm{C}=63.3 \%)$ while $18.3 \%(\mathrm{C})-24.6 \%$ (E) of caregivers had never attended school. In both groups the source of income was mainly the parents $(E=79.2 \%$; $C=86.6 \%)$, while some children depended on their grandparents for support (E $=30.8 \% ; \mathrm{C}=20.0 \%$ ). The majority of caregivers depended on social grants (child grant: $\mathrm{E}=75.4 \%, \mathrm{C}=78.3 \%$; pension grant: $\mathrm{E}=24.6 \%$, $\mathrm{C}=16.7 \%$ ). The monthly income of $65 \%$ of households in both groups was $\leq \mathrm{R} 1000(\mathrm{E}=66.2 \% ; \mathrm{C}=68 \%)$. Firewood was the main source of cooking fuel $(\mathrm{E}=98.5 \%$; $\mathrm{C}=95 \%)$, while electricity was available to some of the households $(\mathrm{E}=21.5 \% ; \mathrm{C}=21.7 \%)$. The main source of water was communal taps $(\mathrm{E}=76.9 \% ; \mathrm{C}=83.3 \%)$, while water from rivers $(\mathrm{E}=32.3 \% ; \mathrm{C}=31.7 \%)$ and wells $(\mathrm{E}=35.5 \% ; \mathrm{C}=8.3 \%)$ was also used. Some of the households used more than one source of water, as communal tap water was not available every day of the week.

\section{Anthropometric status of children}

Table 1 indicates that $20 \%$ of children were stunted, $8 \%$ underweight and $5 \%$ wasted in both groups at baseline. At baseline, there were no statistically significant differences between the $\mathrm{E}$ and $\mathrm{C}$ groups regarding height for age, weight for age, height for weight and BMI/A. None of the anthropometric values changed significantly in either group after the intervention (95\% CI for median difference 0 - 0).

A relatively high percentage of children had a weight for age in the 'risk for overweight' and 'overweight' categories, with $21.2 \%$ in the E group and $15.8 \%$ in the $\mathrm{C}$ group.

Less than $5 \%$ of children in both the $\mathrm{E}$ group and $\mathrm{C}$ group were wasted or severely wasted as defined by weight for height, while $4.6 \%$ of children in the E group and $4.8 \%$ in the $\mathrm{C}$ group were at risk of becoming overweight.

The above results were confirmed by BMI/A, with very few children in both $\mathrm{E}$ and $\mathrm{C}$ groups having a low $\mathrm{BMI} / \mathrm{A}$, while $\sim 15 \%$ in the $\mathrm{E}$ group and $14 \%$ in the $\mathrm{C}$ group were either at risk of becoming overweight or already overweight.

\section{Micronutrient status}

Very few caregivers gave consent for children's blood samples to be taken for determining vitamin $\mathrm{A}$ and iron status. Hence, the micronutrients results were not compared owing to low and unequal numbers in both groups. 


\section{Vitamin A status}

At baseline, nearly one-third of children had marginal vitamin A status (100.0 $199.9 \mu \mathrm{g} / \mathrm{L})$ in both groups $(\mathrm{E}=38.5 \%$; $\mathrm{C}=$ $30.8 \%), 7.7 \%$ of children in the $\mathrm{E}$ group had vitamin A deficiency $(<100 \mu \mathrm{g} / \mathrm{L})$, while in the $\mathrm{C}$ group no low vitamin $\mathrm{A}$ values were detected (Table 2). Before intervention more than $50 \%$ of children had an adequate vitamin A status and after intervention, the majority of children in the $\mathrm{E}$ and the $C$ groups had a normal to well-nourished vitamin A status.

\section{Iron status}

According to the categories for indicators of iron status, the number of children who were in the 'adequate' categories for serum iron, serum ferritin, serum transferrin and percentage transferrin saturation did not change in either group following the intervention (Table 3). As far as iron status was concerned, all of the parameters of iron status in both groups indicated that the majority of children had adequate iron status both pre and post intervention.

\section{Discussion}

High levels of poverty were evident in the participants as indicated by the majority of caregivers being unemployed and relying on child support grants for income, which could have had a negative effect on nutritional status of the children. In contrast, Smuts et al. ${ }^{[20]}$ showed that much lower numbers of households depend on child support grants for their income in rural areas of the Eastern Cape and KwaZulu-Natal Provinces compared with our results. In a study done in rural localities of North-West Ethiopia, preschool children who belonged to families with low income were at greater risk of being wasted, underweight and stunted. ${ }^{[21]}$

Another factor possibly contributing to the high poverty levels observed in the current study could be the high level of illiteracy ( $17 \%$ of caregivers), which is comparable with other studies conducted in $\mathrm{SA}^{[3]}$ and rural Uganda. ${ }^{[22]}$ A low literacy rate can contribute to caregivers getting lowpaying jobs, resulting in low income when compared with their counterparts.

In the current study, nearly one-third of households were getting water from the river, a borehole or a well. Matthews et $a l .{ }^{[23]}$ indicated that in underdeveloped areas of North-Western Nigeria, the common sources of drinking water were rivers or lakes (24\%), private wells $(23 \%)$, taps inside the house (18.7\%) and boreholes (14.1\%). The main source of drinking water in the rural districts of KwaZulu-Natal and Eastern Cape was a river $\left(50 \%\right.$ and $76 \%$, respectively) ${ }^{[20]}$ A considerable number of people in low socioeconomic rural areas still do not have
Table 1. Z-score classification of HAZ, WAZ, WHZ and BMI/A at baseline ${ }^{[19]}$

\begin{tabular}{|c|c|c|c|c|}
\hline$\underline{Z \text {-score classification }}$ & Interpretation & $\begin{array}{l}\text { E group } \\
(N=66), \%\end{array}$ & $\begin{array}{l}\text { C group } \\
(N=63), \%\end{array}$ & $\begin{array}{l}95 \% \text { CI for } \\
\text { median } \\
\text { difference }\end{array}$ \\
\hline \multicolumn{5}{|l|}{ HAZ WHO classification } \\
\hline$<-3 S D$ & Severely stunted & 4.6 & 1.6 & $0-0$ \\
\hline-3 SD $-<-2 S D$ & Stunted & 15.2 & 19.4 & $0-0$ \\
\hline-2 SD $-<-1 S D$ & Mildly stunted & 0 & 0 & \\
\hline$-1 \mathrm{SD}-+1 \mathrm{SD}$ & Normal height & 53.0 & 48.4 & $0-0$ \\
\hline$>+1 S D-\leq+2 S D$ & Normal height & 27.3 & 30.7 & $0-0$ \\
\hline \multicolumn{5}{|l|}{ WAZ WHO classification } \\
\hline$<-3 S D$ & $\begin{array}{l}\text { Severely } \\
\text { underweight }\end{array}$ & 1.5 & 0 & $0-0$ \\
\hline$-3 \mathrm{SD}-<-2 \mathrm{SD}$ & Underweight & 6.1 & 8.0 & $0-0$ \\
\hline$-2 \mathrm{SD}-<-1 \mathrm{SD}$ & Mildly underweight & 0 & 0 & \\
\hline$-1 \mathrm{SD}-+1 \mathrm{SD}$ & Normal WAZ & 71.2 & 76.2 & $0-0$ \\
\hline$>+1 \mathrm{SD}-\leq+2 \mathrm{SD}$ & $\begin{array}{l}\text { Possible growth } \\
\text { problem }\end{array}$ & 19.7 & 11.0 & $0-0$ \\
\hline$>+2 S D-\leq+3 S D$ & $\begin{array}{l}\text { Possible growth } \\
\text { problem }\end{array}$ & 1.5 & 4.8 & $0-0$ \\
\hline \multicolumn{5}{|l|}{ WHZ WHO classification } \\
\hline$<-3 S D$ & Severely wasted & 1.5 & 0 & $0-0$ \\
\hline$-3 \mathrm{SD}-<-2 \mathrm{SD}$ & Wasted & 3.0 & 4.8 & $0-0$ \\
\hline$-2 \mathrm{SD}-<-1 \mathrm{SD}$ & Mildly wasted & 0 & 0 & \\
\hline$-1 \mathrm{SD}-+1 \mathrm{SD}$ & Normal WHZ & 87.9 & 88.8 & $0-0$ \\
\hline$>+1 \mathrm{SD}-\leq+2 \mathrm{SD}$ & $\begin{array}{l}\text { Possible risk of } \\
\text { overweight }\end{array}$ & 4.6 & 4.8 & $0-0$ \\
\hline$>+2 \mathrm{SD}-\leq+3 \mathrm{SD}$ & Overweight & 3.0 & 1.6 & $0-0$ \\
\hline \multicolumn{5}{|c|}{ BMI/A $z$-score WHO classification } \\
\hline$<-3 \mathrm{SD}$ & Severely wasted & 1.5 & 0 & $0-0$ \\
\hline$-3 S D-<-2 S D$ & Wasted & 3.0 & 0 & $0-0$ \\
\hline$-2 \mathrm{SD}-<-1 \mathrm{SD}$ & Normal & 0 & 0 & \\
\hline$-1 \mathrm{SD}-+1 \mathrm{SD}$ & Normal BMI/A & 80.3 & 85.7 & $0-0$ \\
\hline$>+1 \mathrm{SD}-\leq+2 \mathrm{SD}$ & $\begin{array}{l}\text { Possible risk of } \\
\text { overweight }\end{array}$ & 9.1 & 12.7 & $0-0$ \\
\hline$>+2 \mathrm{SD}-\leq+3 \mathrm{SD}$ & Overweight & 6.1 & 1.6 & $0-0$ \\
\hline
\end{tabular}

Table 2. Vitamin A status of children at baseline and post intervention

\begin{tabular}{|c|c|c|c|c|c|}
\hline \multirow[b]{2}{*}{$\begin{array}{l}\text { Serum vitamin A } \\
\text { categories }\end{array}$} & \multirow{2}{*}{$\begin{array}{l}\text { Serum vitamin } \\
\text { A concentration } \\
\text { categories }\end{array}$} & \multicolumn{2}{|c|}{ E group } & \multicolumn{2}{|c|}{ C group } \\
\hline & & $\begin{array}{l}\text { Baseline, \% } \\
(N=13)\end{array}$ & $\begin{array}{l}\text { Post, \% } \\
(N=23)\end{array}$ & $\begin{array}{l}\text { Baseline, \% } \\
(N=26)\end{array}$ & $\begin{array}{l}\text { Post, \% } \\
(N=38)\end{array}$ \\
\hline $\begin{array}{l}\text { Vitamin A } \\
\text { deficiency }\end{array}$ & $<100 \mu \mathrm{g} / \mathrm{L}$ & 7.7 & - & - & - \\
\hline $\begin{array}{l}\text { Marginal vitamin } \\
\text { A status }\end{array}$ & $100-199.9 \mu \mathrm{g} / \mathrm{L}$ & 38.5 & - & 30.8 & \\
\hline Adequate status & $200-299.9 \mu \mathrm{g} / \mathrm{L}$ & 53.9 & 30.4 & 53.9 & 5.3 \\
\hline $\begin{array}{l}\text { Normal/well- } \\
\text { nourished status }\end{array}$ & $\geq 300 \mu \mathrm{g} / \mathrm{L}$ & - & 69.6 & 15.4 & 94.7 \\
\hline
\end{tabular}


Table 3. Iron status children 3 - 5 years, pre and post intervention

\begin{tabular}{|c|c|c|c|c|c|}
\hline \multirow[b]{2}{*}{ Iron indicators } & \multirow[b]{2}{*}{ Serum concentration } & \multicolumn{2}{|c|}{ E group } & \multicolumn{2}{|c|}{ C group } \\
\hline & & Baseline (N=17), \% & Post $(N=29), \%$ & Baseline $(N=26), \%$ & Post $(N=40), \%$ \\
\hline \multicolumn{6}{|l|}{ Serum iron } \\
\hline Depletion & $<5.0 \mu \mathrm{mol} / \mathrm{L}$ & 5.9 & 3.5 & - & 2.5 \\
\hline Adequate & $5.0-16.7 \mu \mathrm{mol} / \mathrm{L}$ & 88.2 & 75.9 & 88.5 & 65.0 \\
\hline High & $>16.7 \mu \mathrm{mol} / \mathrm{L}$ & 5.9 & 20.7 & 11.5 & 32.5 \\
\hline \multicolumn{6}{|l|}{ Serum ferritin } \\
\hline Adequate & $7-140 \mathrm{ng} / \mathrm{mL}$ & 100 & 96.6 & 96.2 & 100 \\
\hline High & $>140 \mathrm{ng} / \mathrm{mL}$ & - & 3.5 & 3.9 & - \\
\hline \multicolumn{6}{|l|}{ Serum transferrin } \\
\hline Adequate & $1.5-3.5 \mathrm{~g} / \mathrm{L}$ & 94.1 & 96.6 & 100 & 97.5 \\
\hline High & $>3.5 \mathrm{~g} / \mathrm{L}$ & 5.9 & 3.5 & - & 2.5 \\
\hline \multicolumn{6}{|c|}{ Transferrin saturation } \\
\hline Low & $<17 \%$ & 5.9 & 3.5 & - & 2.5 \\
\hline Adequate & $17-42 \%$ & 94.1 & 96.6 & 100 & 95.0 \\
\hline High & $>42 \%$ & - & - & - & 2.5 \\
\hline
\end{tabular}

access to clean, safe water, as they still use water from rivers, dams or lakes.

In the current study, stunting, underweight and wasting (95\% CI 0 - 0) did not change in either group after implementation of the NEIP, which was implemented for a period of 1 year. A similar observation was made in the study undertaken in the capital city of Anhui Province in China, where height for age and weight for age did not improve significantly after implementation of a nutrition education intervention that was implemented for 1 year by trained nutrition graduates and research assistants. ${ }^{[2]}$ Contrary to these findings, Ghoneim et al. ${ }^{[25]}$ found that the number of children aged 2 - 5 years from three daycare centres in Alexandria, Egypt, who were stunted and wasted decreased significantly after 1 year of implementing health education among the parents. The most obvious reason for the marked improvement in the study by Ghoneim et al. ${ }^{[25]}$ was the provision of two meals and fruit snacks per day. The NEIP in this present study was implemented by one person over a period of 1 year, while the study by Ghoneim et al. ${ }^{[25]}$ included higher coverage since it was implemented by two or more people over 2 years. In addition, the current study did not include food supplementation.

Before intervention, more than $50 \%$ of children had an adequate vitamin A status; after intervention, the majority of children in both the $\mathrm{E}$ and $\mathrm{C}$ groups had a normal to good vitamin A status. The national vitamin A supplementation programme that was implemented at the same time as this intervention may have affected vitamin A levels, and this is most probably the reason why improvement occurred in both the $\mathrm{E}$ and $\mathrm{C}$ groups. As far as iron status was concerned, all of the parameters of iron status indicated that the majority of children had adequate iron status, even before intervention. The national food fortification programme could possibly have had an effect on the results. Furthermore, because the sample of children on which blood could be drawn was so small, these results should be interpreted with caution.

\section{Conclusions}

The NEIP did not have a significant effect on anthropometric nutritional status and micronutrient status of children, as there was no change observed in these parameters after intervention. Lack of improvement may be attributed to the fact that the majority of children had normal nutritional status (anthropometric and micronutrient) at baseline, leaving little room for improvement. The relatively short intervention period could also not have allowed enough time for significant physiological change in nutritional status to occur.

\section{Recommendations}

The NEIP developed in the present study can be adapted to include the use of media that can increase coverage. Future studies should develop nutrition intervention strategies only after the collection of baseline data in order to address the identified needs of the community being studied.

Acknowledgements. We would like to thank the National Research Foundation, the University of Venda and the Department of Science and Technology for funding the project.

\section{References}

1. United Nations Standard Committee on Nutrition (UNSCN). Fifth Annual Report on the World Nutrition Situation: Nutrition for improved development outcomes. Sudbury, UK: Lavenham Press, 2004.

2. UNSCN. Tackling the Double Burden of Malnutrition: A Global Agenda. SCN News, Number 32 mid-2006. Sudbury, UK: Lavanham Press, 2006.

3. Shisana O, Labadarios D, Rehle T, et al. South African National Health and Nutrition Examination Survey (SANHANES-1). Cape Town: HSRC press, 2013.

4. UNSCN. Sixth Report on the World Nutrition Situation. Progress in Nutrition. Sudbury, UK: Lavanham Press, 2011.

5. United Nations Administrative Committee on Coordination Sub-Committee on Nutrition (ACC/SCN) in collaboration with International Food Policy Research International (IFPRI) United Nations, Geneva. Fourth Report on the World Nutrition Situation: The World Nutrition Situation. Nutrition Throughout the Life Cycle. Geneva: ACC/SCN, 2000.

6. United Nations Children's Fund (UNICEF), United Nations University (UNU), World Health Organization (WHO). Iron Deficiency Anaemia - Assessment, Prevention and Control: A Guide for Programme Managers. Geneva: WHO, 2001.

7. Begin F, Greig A. Food Fortification in West Africa: Assessment of Opportunities and Strategies. Ottawa, USA: Micronutrient Initiative, 2002.

8. The South African Vitamin A Consultative Group (SAVACG); Labadarios D, van Middelkoop A, eds; and assisted by Coutsoudis A, Eggers RR, Hussey G, Jsselmuiden G, and Kotz JP. Children Aged 6 to 71 months in South Africa, 1994: Their Anthropometric, Vitamin A, Iron and Immunization Coverage Status. Johannesburg: SAVACG, 1995.

9. Food and Agriculture Organization (FAO). Community-based Food and Nutrition Programmes: What Makes Them Successful. A Review and Analysis of Experience. Rome: FAO United Nations, 2003:47. 
10. Rivera JA, Hotz C Gonzalez-Cossio T, Neufeld L, Garcia-Guerra A. The effect of micronutrients deficiencies on child growth: A review of results from community-based supplementation trials. J Nutr 2003;133 (11 Suppl 2):S4010-S40120.

11. WHO; de Benoist B, Mclean E, Egli I, Cogswell M, eds. Worldwide Prevalence of Anaemia 1993 - 2005: WHO Global Database on Anaemia. Geneva: WHO, 2008.

12. Faber M, Wenhold F. Nutrition in contemporary South Africa. Water SA 2007;33(3). http://www.wrc.org.za (accessed 20 June 2010).

13. Aphane J, Chadha ML, Oluoch MO. Increasing the Consumption of Micronutrient-rich Foods Through Production and Promotion of Indigenous Foods. FAO-AVRDC International workshop proceedings, Arusha, Tanzania. Rome: FAO United Nations, 2003.

14. Lee RD, Nieman DC. Nutritional Assessment. 4th ed. New York: Mcgraw-Hill companies, 2007

15. Voster HH, Love P, Browne C. Development of food-based dietary guidelines for South Africa: The process. S Afr J Clin Nutr 2001;14(3):S3-S6.

16. Bourne LT. South African paediatric food-based dietary guidelines. Matern Child Nutr 2007;3(4):227-229. [http://dx.doi.org/10.1111/j.17408709.2007.00107.x]

17. Smolin LA, Grosvenor MB. Nutrition: Science and Applications. New York: John Wiley and Sons Inc., 2008.
18. Burgess A, Glasauer P. Family Nutrition Guide. Rome: FAO United Nations, 2004 19. WHO. WHO AnthroPlus for Personal Computers Manual, Software for Assessing Growth of the World's Children and Adolescents. Geneva: WHO, 2009.

20. Smuts CM, Faber M, Schoeman SE, et al. Socio-demographic profiles and anthropometric status of 0 to 71 month-old children and their caregivers in rural districts of Eastern and Kwa-Zulu Natal provinces of South Africa. S Afr J Clin Nutr 2008;21(3):117-124.

21. Edris M. Assessment of nutritional status of pre-school children of Gumbrit, North West Ethiopia. Ethop J Health Dev 2007;21(2):125-129.

22. Wamani H, Astrøm AN, Peterson S, Tumwine JK, Tylleskar T. Predictors of poor anthropometric status among children under 2 years of age in rural Uganda. Public Health Nutr 2006;9(3):320-326.

23. Matthews AK, Amodu AD, Sani I, Solomon SD. Infant feeding practices and nutritional status of children in North Western Nigeria. Asian J Clin Nutr 2009;1(1):12-22.

24. Hu C, Ye D, Li Y, Huang Y, Gao Y, Wang S. Evaluation of a kindergarten-based nutrition education for pre-school children in China. Public Health Nutr 2009;13(2):253-260. [http://dx.doi.org/10.1017/S1368980009990814]

25. Ghoneim EH, Hassan MHA, Amine EK. An intervention programme for improving the nutritional status of children aged 2 to 5 years in Alexandria. Eastern Mediterr Health J 2004;10(6):828-843. 